U.S. GEOLOGICAL SURVEY CIRCULAR 920

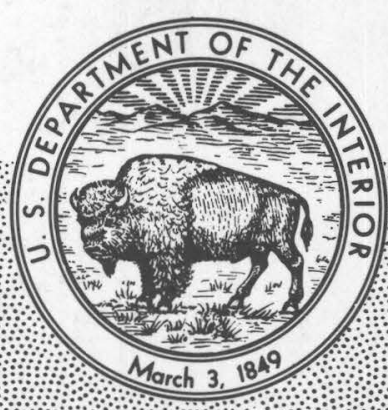

The Conterminous United States Mineral Assessment Program: Background Information to Accompany Folio of Geologic, Geochemical, Geophysical, Remote Sensing, and Mineral Resource Maps of the Wallace $1^{\circ} \times 2^{\circ}$ Quadrangle, Montana and Idaho 



\section{The Conterminous United States}

\section{Mineral Assessment Program:}

Background Information to Accompany

Folio of Geologic, Geochemical,

Geophysical, Remote Sensing, and

Mineral Resource Maps of the

Wallace $1^{\circ} \times 2^{\circ}$ Quadrangle,

Montana and Idaho

By Jack E. Harrison, David L. Leach, M. Dean Kleinkopf, Carl L. Long, Larry C. Rowan, and Richard F. Marvin

U.S. GEOLOGICAL SURVEY CIRCULAR 920 
United States Department of the Interior DONALD PAUL HODEL, Secretary

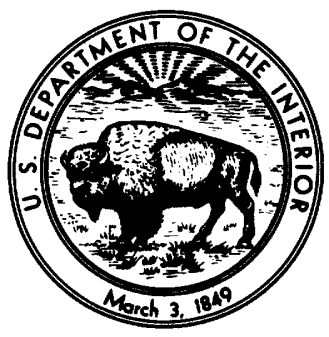

\section{U.S. Geological Survey}

Dallas L. Peck, Director 


\section{CONTENTS}

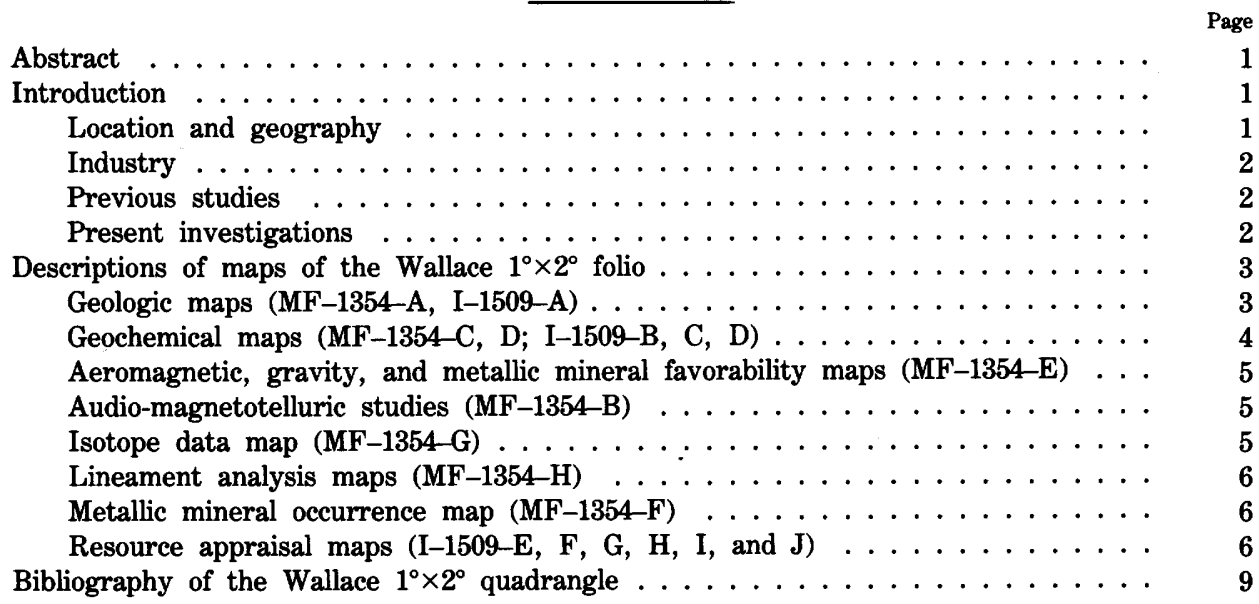

\section{ILLUSTRATION}

FIGURE 1. Index map showing location of the Wallace and adjacent $1^{\circ} \times 2^{\circ}$ quadrangles, Montana, Idaho, and Washington

\section{TABLES}

TABLE 1. Principal maps of the Wallace $1^{\circ} \times 2^{\circ}$ quadrangle folio . . . . . . . . . . . . . . . . . .

2. Supplemental open-file reports and maps of the Wallace $1^{\circ} \times 2^{\circ}$ quadrangle folio ............ 


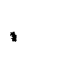




\title{
THE CONTERMINOUS UNITED STATES MINERAL ASSESSMENT PROGRAM: BACKGROUND INFORMATION TO ACCOMPANY FOLIO OF GEOLOGIC, GEOCHEMICAL, GEOPHYSICAL, REMOTE SENSING, AND MINERAL RESOURCE MAPS OF THE WALLACE $1^{\circ} \times 2^{\circ}$ QUADRANGLE, MONTANA AND IDAHO
}

\author{
By Jack E. Harrison, David L. Leach, M. Dean Kleinkopf, \\ Cart L. Long, Larry C. Rowan, and Richard f. Marvin
}

\section{ABSTRACT}

The Wallace $1^{\circ} \times 2^{\circ}$ quadrangle in Montana and Idaho was studied by an interdisciplinary research team that included geologists, geochemists, and geophysicists, as well as specialists in isotopic dating and remote sensing. The basic data resulting from these studies, as well as the final metallic mineral resource assessments, are published as a folio of maps, figures, tables, and accompanying discussions. This circular provides background information on the studies and lists the published components of the resource appraisal. An extensive bibliography lists both specific and general references that apply to this geoscience study of the quadrangle.

\section{INTRODUCTION}

This circular, as well as a folio of separately published maps, is part of a series of U.S. Geological Survey reports that contain information on the mineral resources and mineral resource potential of the conterminous United States. The studies described herein are for the Wallace $1^{\circ} \times 2^{\circ}$ quadrangle in Montana and Idaho (fig. 1). This circular and the folio maps were prepared under the Conterminous United States Mineral Assessment Program (CUSMAP). CUSMAP is intended to provide regional mineral appraisal information to assist in formulating a sound, long-range national minerals policy and to assist Federal, State, and local governments in making decisions that involve land-use policy. In addition, the products of CUSMAP are intended to increase geological, geochemical, and geophysical knowledge of the conterminous United States. In accomplishing these goals, the program provides a regional geologic and mineral resource framework for specific studies, such as the mineral appraisal of wilderness areas and guidance for mineral exploration.

\section{LOCATION AND GEOGRAPHY}

The Wallace $1^{\circ} \times 2^{\circ}$ quadrangle covers about $6,450 \mathrm{mi}^{2}$ in northwestern Montana and adjacent parts of Idaho between lat $47^{\circ}$ and $48^{\circ} \mathrm{N}$. and long $114^{\circ}$ and $116^{\circ} \mathrm{W}$. (fig. 1). The area includes part of the Cabinet Mountains, Bitterroot Range, and Salish Mountains, where major valleys are generally at elevations of 2,500 to $3,000 \mathrm{ft}$ and mountain peaks at 5,000 to 7,000 ft. The crest of the Bitterroot Range in the western part of the area forms the State line between Montana and Idaho. The high point in the quadrangle is at about $8,000 \mathrm{ft}$ on Squaw Peak in the southeastern part of the area. The quadrangle includes most of Flathead Lake, which is in the northeast corner of the area. Principal drainages are the Clark Fork, Flathead, Saint Regis, Coeur d'Alene, and St. Joe Rivers. Many small towns and communities are scattered across the area; the largest towns are Wallace, Idaho, near the west edge of the quadrangle, and Polson, Mont., in the northeast, at the south end of Flathead Lake. The Flathead Indian Reservation occupies most of the eastern third of the quadrangle. The Montana National Bison Range is in the south-central part of the reservation. 


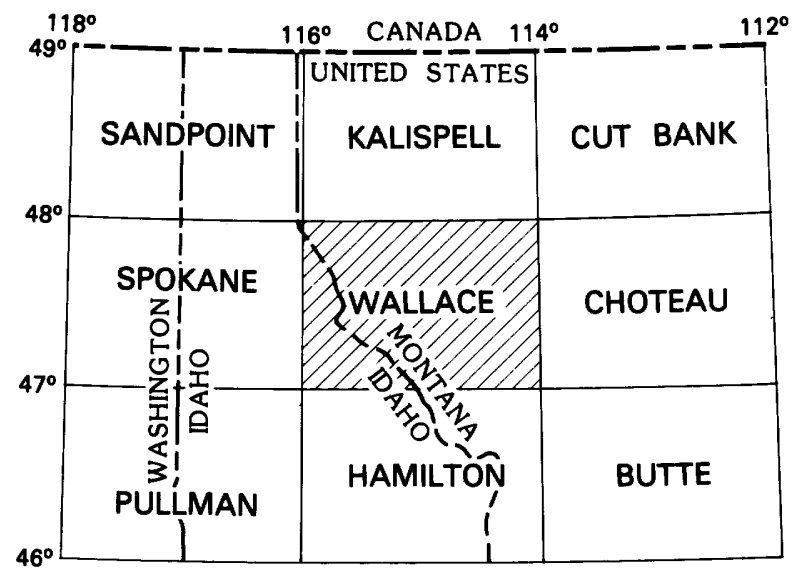

FiguRE 1.-Index map showing location of the Wallace and adjacent $1^{\circ} \times 2^{\circ}$ quadrangles, Montana, Idaho, and Washington.

More than half the quadrangle is on national forests, which include parts of the Lolo, St. Joe, Coeur d'Alene, Kaniksu, Kootenai, and Flathead National Forests.

Most of the area is accessible by a network of State and Federal highways and then by county and forest roads. Permission from the Flathead Tribal Council is advisable for use of the back roads on the Indian reservation. A few parts of the area are accessible only by foot trail.

\section{INDUSTRY}

Principal industries in the area are logging and mining. Most of the timber is on national forests, although significant timber is also held on the Flathead Indian Reservation and by private companies. The largest sawmills in the quadrangle are at Thompson Falls, Superior, Polson, and Pablo, Mont. Many logs are hauled westward to Saint Maries, Idaho, and southeastward to Missoula, Mont. Mining activity has been scattered over much of the area. The quadrangle includes the eastern half of the world-famous Coeur d'Alene silver mining district, as well as many smaller districts such as those around Murray, Idaho, and Saint Regis and Superior, Mont.

\section{PREVIOUS STUDIES}

Geology and mineral resources in parts of the Wallace quadrangle have been studied in various degrees of detail since the turn of the century.
Early interest was centered around the mining districts (MacDonald, 1906; Ransome and Calkins, 1908; Pardee, 1911; Calkins and Jones, 1914; Jones, 1919; Umpleby and Jones, 1923). Restudy of some of the same districts and new study of others occurred in the 1930's (Shenon and Taylor, 1936; Shenon, 1938) and again in the late 1940's and during the 1950's (Lyden, 1948; Cook, 1955; Hosterman, 1956; Sahinen, 1957; Weis and others, 1958; Campbell, 1960; Fryklund, 1964; Hobbs and others, 1965; Johns, 1970). Numerous specialized studies that include observations in the Wallace quadrangle have been done on such diverse topics as glacial geology (Pardee, 1910; Alden, 1953), geochronometry (McDowell, 1971; Armstrong, 1975; Armstrong and others, 1977), geochemistry (Wilson, 1963; Crosby, 1969; Gott and Cathrall, 1980), igneous petrology (Hietanen, 1963), paleontology (Keim and Rector, 1964), geophysics (LaPoint, 1971; Kleinkopf and others, 1972; Wold, 1982), and stratigraphy (Wagner, 1949; Wallace and Hosterman, 1956; Hietanen, 1968; Wells, 1974).

\section{PRESENT INVESTICATIONS}

Systematic collection of data by the U.S. Geological Survey began in 1973 with geologic mapping at a 1:250,000 scale by A. B. Griggs and J. E. Harrison, who later were joined by J. D. Wells. All previous geologic mapping was checked and revised where necessary to meet the improved knowledge of stratigraphic units available in the 1970's. The geologic map was completed in 1981. A detailed stratigraphic study of the Prichard Formation near Plains, Mont., was done by E. R. Cressman in 1980-81. Aeromagnetic and gravity data were accumulated as time and money permitted through the 1970's, and a final effort was made by M. D. Kleinkopf to complete reconnaissance coverage by 1981. Audio-magnetotelluric surveys were conducted by $\mathrm{C}$. L. Long in 1979-81. Background data on the geochemistry of rocks and stratabound mineral occurrences were collected along with the geologic mapping; systematic collection of samples of stream sediments and types of ore deposits was done under the direction of D. L. Leach and J. A. Domenico during the field seasons of 1979 through 1981. Chemical analyses were done by Domenico and D. M. Hopkins in the U.S. Geological Survey laboratories in Golden, Colo. Computer analyses and manipula- 
tion of the data were completed by Leach, H. E. Dawson, and R. J. Goldfarb in 1982. Isotopic dating of rocks and ores was done periodically by $R$. F. Marvin, R. E. Zartman, and J. D. Obradovich as the geologic mapping progressed. Remote sensing data from Landsat images and from side-looking radar were analyzed by L. C. Rowan and T. L. Purdy and field checked by Rowan in 1980 . Data on mineral occurrences in the quadrangle were compiled from published and unpublished sources by Sharon Chesson and R. R. Wallace during 1979 and 1980, were put into the U.S. Geological Survey CRIB (changed to MRDS in 1983) file, and were manipulated by computer in 1981 by Thomas Griffith.

The data and the maps prepared for the Wallace $1^{\circ} \times 2^{\circ}$ quadrangle folio are being released in a series of USGS formal reports and open files (tables 1 and 2).

\section{DESCRIPTIONS OF MAPS OF THE}

\section{WALLACE $1^{\circ} \times 2^{\circ}$ FOLIO}

\section{GEOLOCIC MAPS (MF-1354-A, I-1509-A)}

A colored geologic map and a structure map of the quadrangle are published at a scale of $1: 250,000$ as I-1509-A. These maps are accompanied by detailed map explanations, cross sections, stratigraphic columns, and some explanatory and interpretative text. An uncolored, generalized map at the same scale has only a simple explanation and is published as MF-1354-A. This simplified map is used as an underlay for other maps of the Wallace CUSMAP folio that show geochemical, geophysical, and mineral resource data.

Bedrock in the Wallace quadrangle consists dominantly of metasedimentary rocks of the Middle Proterozoic Belt Supergroup. About $60,000 \mathrm{ft}$ of Belt rocks are exposed on a single thrust plate. The rocks are mostly fine grained clastics and carbonates that show a variety of bedding characteristics and sedimentary structures. Regional metamorphism increases from diagenetic mineral assemblages at the top of the section downward through a chlorite-sericite zone into a garnet zone of the greenschist facies in the lowest exposed rocks. Metamorphism also increases near intrusive rocks and is as high as the amphibolite facies in the southwestern part of the quadrangle, where metamorphic isograds related to the Idaho batholith have been mapped by Hietanen (1963, 1968) and Lang (Lang and Rice, 1982).

Precambrian sills and dikes of dioritic to gabbroic composition have been intruded into Belt rocks. Most occur in the lower part of the Prichard Formation, but a few are found in the Burke, Wallace, Helena, Mount Shields, and Garnet Range Formations. The dikes and sills represent more than one episode of intrusion (Harrison, 1972).

Cambrian sedimentary rocks unconformably overlie Belt rocks in the southeastern and north-central parts of the quadrangle. The rocks consist of a lower quartzite overlain by shale, limestone, and dolomite.

Stocks and dikes ranging in composition from diorite to granite are exposed in many parts of the quadrangle. In a regional sense, these intrusive rocks are outliers of the Idaho batholith, which is about $40 \mathrm{mi}$ south of the quadrangle, and of the batholithic terrane of eastern Washington and northern Idaho, an area about $70 \mathrm{mi}$ northwest of the quadrangle. Ages of these intrusions within the Wallace quadrangle range from about 120 million years (m.y.) to about 35 m.y. (Marvin and others, 1984) or Cretaceous to Oligocene. Many of the plutons are along or near high-angle faults, and where they encounter thrust faults, most appear to intrude through or at least into the thrusts. A zone of intrusions extends northnortheast from the St. Joe fault at the west edge of the quadrangle through the Coeur d'Alene mining district near Wallace, Idaho, to the northeast side of the Clark Fork valley near Trout Creek, Mont. Many geologists have considered this zone to reflect some deep crustal flaw whose intersection with a zone of west-northwest-trending fractures (the Lewis and Clark line) near Wallace may control the location of the Coeur d'Alene mining district.

Tertiary sedimentary and volcanic rocks underlie small parts of the quadrangle and are most abundant in the valley of Ninemile Creek near the southeast corner of the area. The sedimentary rocks include conglomerate, shale, coal, and volcanic ash. A small volcanic field in the northeast part of the quadrangle contains mostly volcanic agglomerate, conglomerate, and breccia, plus dacite tuff. 
Unconsolidated deposits in the quadrangle include widespread occurrences of Pleistocene glacial debris from both continental and mountain glaciers, as well as lake silt from glacial Lake Missoula. Alluvial deposits occur along most stream courses.

Structure in the area is complex, and many features are strikingly displayed on the maps. A southeast-trending zone of strike-slip and highangle faults transects the quadrangle from the center of the west edge to the southeast corner; this zone is part of the Lewis and Clark line (Billingsley and Locke, 1939). The large intermontane valley at the east edge of the quadrangle occurs along multiple high-angle faults in the Rocky Mountain trench. A major strike-slip fault (the Hope) extends from near the center of the quadrangle northwest along the valley of the Clark Fork; another (the St. Marys) extends from about the same point near the center of the quadrangle eastward along the valley of the Flathead River. Numerous thrust faults are scattered over the quadrangle; these are commonly cut by the abundant high-angle faults that occur in most of the area. The most common folds are broad open structures that are outlined by the patterns of lithologic units; a few tight folds or folds that have one vertical to overturned limb are present locally.

\section{GEOCHEMICAL MAPS (MF-1354-C, D; (-1509-B, C, D)}

The geochemical maps contain data from a geochemical survey conducted in the Wallace quadrangle from 1978 to 1981 . These data show the distribution and abundance of selected elements and were used to delineate areas having anomalous concentrations of those elements. The geochemical survey consisted of the collection and analysis of samples of stream sediments and nonmagnetic heavy-mineral concentrations from 1,229 locations. An unbalanced, four-level, nested sampling procedure was used to partition the total variability of the data among four major sources of variability.

All samples were prepared and analyzed by the U.S. Geological Survey laboratories in Golden, Colo. The stream sediments were air dried and then sieved using an 80 -mesh sieve. The material passing through the 80 -mesh sieve was pulverized to less than 100 mesh for analysis. Heavy-mineral concentrates were collected using a standard gold pan. Commonly, 3-4 kilograms of composited sediment were collected to yield the desired $30-60$ grams of concentrate. These samples were air dried, and the highly magnetic material was removed by an electromagnet. Any low-density material remaining in the concentrate was separated by allowing the heavier fraction to settle through bromoform (specific gravity of 2.8). The resulting heavy-mineral fraction was then separated into a nonmagnetic and a magnetic fraction using a Frantz Isodynamic separator ${ }^{1}$ at a setting of 0.6 ampere with $15^{\circ}$ forward and $15^{\circ}$ side settings. The nonmagnetic fraction was pulverized in an agate mortar before analysis.

Each stream-sediment and nonmagnetic heavymineral sample was analyzed semiquantitatively for 31 elements using an optical emission spectrograph. Each stream-sediment sample was also analyzed by atomic absorption spectrometry for total-metal concentrations of silver, bismuth, cadmium, copper, lead, antimony, and zinc, because this method has lower detection limits than possible by emission spectrography. These elements were selected because they are important constituents of most of the mineral deposits in the quadrangle. Atomic absorption spectrometry was also used to determine concentrations of this same suite of elements (except for cadmium) that were partially extractable in weak hydrochloric acid. All the data for the geochemical survey are available on computer tape from the National Technical Information Service (McDanal and others, 1982) and in U.S. Geological Survey Open-File Report 82-494 (Leach and others, 1982). The latter report describes in detail the procedure used in the survey, as well as provides a variety of statistical summaries and estimates based on the data sets.

Results have been released as U.S. Geological Survey Open-File Reports that include maps at a scale of 1:250,000, which show distribution and abundance of antimony, cadmium, copper, lead, silver, and zinc in nonmagnetic heavy-mineral concentrates and in stream sediments for both total and partially extractable metals. Included in the reports are contour maps for each of the elements used in identifying broad regional geochemical trends. One map (Open-File Report 84-700) shows

${ }^{1}$ The use of trade names in this report is for descriptive purposes only and does not imply endorsement by the U.S. Geological Survey. 
the distribution and abundance of bismuth, molybdenum, tin, and tungsten in nonmagnetic heavymineral concentrates; these data were used to help develop the resource map for porphyry molybdenum-tungsten deposits.

For each of the three data sets-nonmagnetic heavy minerals, total metals in stream sediments, and partially extractable metals in stream sediments-maps were compiled to show the suite of elements that may be present in anomalous concentrations at each sample location in the quadrangle. These maps (I-1509-B, C, and D) were used to help derive several of the mineral-resource appraisal maps.

In addition to these data maps, an interpretative geochemical map (MF-1354-C) includes a text that describes the steps used to determine the geochemical favorability for mesothermal baseand precious-metal vein deposits in the Wallace quadrangle.

\section{AEROMAGNETIC, GRAVITY, AND METALLIC MINERAL FAVORABILITY MAPS (MF-1354-E)}

The aeromagnetic and gravity maps of the Wallace quadrangle were prepared from four separate aeromagnetic surveys totaling about 16,000 line miles and from nearly 2,100 gravity stations spaced about $5 \mathrm{mi}$ apart (Bankey and Kleinkopf, 1982; Bankey and others, 1982; Wold, 1982; U.S. Geological Survey, 1978, 1979; Wilson, 1979; Kleinkopf and others, 1972; Douglas, 1972; LaPoint, 1971). Total intensity magnetic, Bouguer gravity, and magnetic and gravity residual maps were used to locate and outline the configuration of buried intrusions and to delineate major faults and shear zones in the subsurface.

The aeromagnetic and gravity anomaly data were used to help evaluate the quadrangle for porphyry molybdenum-tungsten, mesothermal baseand precious-metal veins, and epithermal silver deposits. These types of hydrothermal deposits are assumed to be related to granitic intrusions, and the magnetic anomaly data provide the most diagnostic criteria for locating buried plutons and for defining the subsurface configuration of exposed plutons. Gravity information helps outline major structural trends, and upward continuation of anomalies helps to define areas that may contain blind intrusions.
The results of the magnetic and gravity study are summarized on a map that shows geophysical favorability for metallic-mineral-bearing hydrothermal veins. An arbitrary system of favorability was used to rank areas from most favorable (3 points) to unfavorable ( -1 point). The results of this favorability ranking are integrated with audio-magnetotelluric, geochemical, geological, and mineral occurrence data as part of the metallic mineral resource appraisal of the quadrangle (Harrison, Leach, Kleinkopf, Cressman, and others, in press; Long, 1983).

\section{AUDIO-MAGNETOTELLURIC STUDIES (MF-1354-B)}

The regional subsurface resistivity in terrane of the Belt Supergroup was studied using natural source audio-magnetotelluric (AMT) currents. The data were plotted on a 7.5-Hertz map, two 27Hertz maps, and six resistivity cross sections (Long and others, 1981; Long, 1982; Long, 1983). The AMT data identified conductive zones that are inferred to be related to sulfide minerals in certain beds of the Prichard Formation, an altered zone associated with a buried porphyry molybdenum stock, and subsurface extensions of geologic units and structures. This study has demonstrated an effective reconnaissance geophysical method for outlining sulfide-bearing strata that may be within suitably shallow depths for future mineral exploration.

\section{ISOTOPE DATA MAP (MF-1354-C)}

The isotope data map of the Wallace quadrangle shows (1) the sample localities and radiometric ages for 15 samples, as well as sample localities for 20 other samples that gave hybrid or spurious ages, and (2) the location of 36 mines or prospects from which galena was collected for lead isotope analysis. The isotopic ratios of lead indicate that some lead is Precambrian and some is MesozoicCenozoic.

Rocks and minerals from metamorphic and igneous bodies were also dated. The pre-Belt basement gneiss is about $1,665 \mathrm{~m} . \mathrm{y}$. old according to uranium-lead (U-Pb) determinations on zircon. Radiometric dates for rocks of the Belt Supergroup are mostly hybrid (secondary) ages, reflecting the effects of metamorphic, plutonic, thermal, and tectonic events on Belt strata. Several potas- 
sium-argon (K-Ar) mineral ages and U-Pb zircon ages indicate that plutonic activity within the quadrangle occurred at about $100 \mathrm{~m} . \mathrm{y}$. and 50 m.y. ago. The most recent igneous activity, as dated by the K-Ar method, occurred about 30 m.y. ago (mid-Oligocene) and resulted in the formation of the small Hog Heaven volcanic field in the northeastern quadrant of the quadrangle.

\section{LINEAMENT ANALYSIS MAPS (MF-1354-H)}

Linear and arcuate features were mapped on Landsat images and image mosaics to examine possible relations between fracture zones, intrusive bodies, and mineral deposits in the quadrangle. Landsat band 5 and band 7 image mosaics were used for mapping these features in the quadrangle, as well as in the region adjacent to the quadrangle, and digitally processed color-infrared composite images were used for detailed studies in the quadrangle and bordering areas. The linear features mapped on the color-infrared images were digitized to facilitate statistical analysis. Lineaments identified using this approach were compared with mapped fault and fracture zones, aeromagnetic and Bouguer gravity anomalies, and geochemical anomalies, as well as with the distributions of different types of metal deposits. Most of the Cretaceous and Tertiary intrusive bodies are along northeast-trending lineaments, and many are marked by arcuate features.

\section{METALLIC MINERAL OCCURRENCE MAP (MF-1354-F)}

The mineral occurrence map shows the location of about 550 mines and prospects and the kinds of metals found in them. About a third of the mines and prospects are in the Coeur d'Alene mining district in the west-central part of the quadrangle; another third are along the Lewis and Clark line southeast of that district; and the re- mainder are scattered over the quadrangle. Principal products from the mines have been gold, silver, lead, zinc, cadmium, copper, and bismuth. Other commodities that have been produced or are known in the area include molybdenum, tungsten, antimony, nickel, platinum-group metals, and uranium. Symbols on the map identify each known property and show each classified into one of several categories consisting of individual metals or groups of metals. A table lists property name, location, metals known or produced, and references used to characterize the mine or prospect.

\section{RESOURCE APPRAISAL MAPS (I-1509-E, F, G, H, I, AND J)}

Resource appraisal maps have been prepared for placer gold (I-1509-E), stratabound copper-silver (I-1509-F), Sullivan-type stratabound leadzinc-silver (I-1509-G), porphyry molybdenumtungsten, platinum-group metals, and epithermal silver (I-1509-H), and mesothermal base- and precious-metal veins (I-1509-I). In addition, a summary map has been prepared showing all metallic mineral resources (I-1509-J). Each of these maps is accompanied by a pamphlet that explains the resource appraisal system used for all appraisals. In addition, each individual map includes a written description of the occurrence model used for the type of ore deposit being appraised, the criteria for determining various levels of favorability within a subarea of the quadrangle, and numerical values assigned to those levels of favorability. Subareas identified within the quadrangle have been classified into six levels of decreasing favorability and one level of unfavorablility for the type of deposit being evaluated. The numerical scores assigned by the appraisal team are shown for each subarea. Data supporting the scores are shown on the maps; where the data are necessarily generalized, the detailed data can be found in other maps and reports of the Wallace CUSMAP folio. 


\begin{abstract}
Map No.
Author(s) (year of publication)

Subject
\end{abstract}

\begin{abstract}
MF-1354-A
MF-1 354-B

$M F-1354-C$

MF-1354-D

Leach and Goldfarb (In press)---

Harrison, Griggs, and Wells (1981)

Long (1983)

Leach (in press) -

MF-1354-E

MF-1354-F

$M F-1354-G$

$\mathrm{MF}-1354-\mathrm{H}$

I-1509-A

I-1509 B
\end{abstract}

$I-1509-C$

Leach and Hopkins (in press) -

I-1509-D

Leach and Hopkins (in press) - -
Harrison, Domenico, and Leach (in press).

Harrison, Domenico, and Leach (in press).

Harrison, Cressman, Long, Leach, and Domenico (in press).

$\mathrm{I}-1509-\mathrm{H}$

$I-1509-I$

$I-1509-J$
Harrison, Leach, Kleinkopf, and Long (in press).

Harrison, Leach, and Kleinkopf (in press).

Harrison, Leach, Kleinkopf, Cressman, Long, and Domenico (in press).
Generalized geology.

Audio-magnetotelluric studies.

Geochemical favorability for mesothermal base- and precious-metal veins.

Geochemical distribution of lead, zinc, copper, and silver; also geochemical distribution of lead and zinc.

Aeromagnetic, gravity, and metallic mineral favorability maps.

Metallic mineral occurrences.

Geochronometric and isotope data.

Lineament analysis.

Geology and structure.

Distribution of samples of heavymineral concentrates containing anomalous antimony, arsenic, copper, lead, silver, and zinc.

Distribution of stream sediments containing anomalous antimony, bismuth, cadmium, copper, lead, silver, and zinc.

Distribution of stream sediments containing anomalous partially extractable antimony, bismuth, copper, lead, silver, and zinc.

Resource appraisal for placer gold.

Resource appraisal for stratabound copper-silver.

Resource appraisal for stratabound lead-zinc-silver.

Resource appraisal for porphyry molybdenum-tungsten, platinumgroup metals, and epithermal silver.

Resource appraisal for mesothermal base- and precious-metal veins.

Summary of resource potential for metallic minerals. 
TABLE 2.-Supplemental Open-file reports and maps of the Wallace $1^{\circ} \times 2^{\circ}$ quadrangle folio ${ }^{1}$ [OF, U.S. Geological Survey Open-File Report]

\begin{tabular}{|c|c|c|}
\hline Report No. & Author(s) (year of release) & Subject \\
\hline $0 F-81-785$ & Cressman (1981) & Geologic map of the Plains-Perma area. \\
\hline$O F-81-1153$ & Long, Tippens, and Lewis (1981) & Audio magnetotelluric data. \\
\hline $0 F-82-132$ & $\begin{array}{l}\text { Bankey, Brickey, and Kleinkopf } \\
\text { (1982). }\end{array}$ & Principal facts for 1980 gravity stations. \\
\hline $0 F-82-494$ & $\begin{array}{l}\text { Leach, Domenico, Hopkins, Dawson, } \\
\text { and Goldfarb (1982). }\end{array}$ & $\begin{array}{l}\text { Geochemical data and statistical sum- } \\
\text { maries for stream sediments and } \\
\text { nonmagnetic heavy-mineral concentrates. }\end{array}$ \\
\hline OF-82-495 & Cressman (1982) & $\begin{array}{l}\text { Stratigraphic section of Prichard } \\
\text { Formation. }\end{array}$ \\
\hline OF-82-577 & Leach $(1982) \cdots$ & $\begin{array}{l}\text { Geochemical favorability for mesothermal } \\
\text { veins (one } 35-\mathrm{mm} \text { colored slide). }\end{array}$ \\
\hline $0 F-82-581$ & $\begin{array}{l}\text { Harrison, Leach, Kleinkopf, } \\
\text { Cressman, Long, and Domenico } \\
\text { (1982). }\end{array}$ & $\begin{array}{l}\text { Metallic mineral resource appraisal } \\
\text { (nine } 35-\mathrm{mm} \text { colored slides). }\end{array}$ \\
\hline $0 F-82-671$ & Long $(1982)-1$ & $\begin{array}{l}\text { Audio-magnetotelluric surveys (four 35- } \\
\text { mm colored slides). }\end{array}$ \\
\hline $0 F-82-709$ & $\begin{array}{l}\text { Kleinkopf, Harrison, and Bankey } \\
\text { (1982). }\end{array}$ & $\begin{array}{l}\text { Aeromagnetic, gravity, and metallic min- } \\
\text { eral resource favorability (three 35- } \\
\text { mm colored slides). }\end{array}$ \\
\hline $0 F-82-883$ & Bankey and Kleinkopf (1982) & Principal facts for Bouguer gravity map. \\
\hline $0 F-83-304$ & $\begin{array}{l}\text { Leach, Hopkins, Domenico, and } \\
\text { Dawson (1984a). }\end{array}$ & $\begin{array}{l}\text { Geochemical distribution and abundance } \\
\text { of lead. }\end{array}$ \\
\hline $0 F-83-305$ & $\begin{array}{l}\text { Leach, Hopkins, Domenico, and } \\
\text { Dawson (1984b). }\end{array}$ & $\begin{array}{l}\text { Geochemical distribution and abundance } \\
\text { of cadmium. }\end{array}$ \\
\hline $0 F-83-306$ & $\begin{array}{l}\text { Leach, Hopkins, Domenico, and } \\
\text { Dawson (1984c). }\end{array}$ & $\begin{array}{l}\text { Geochemical distribution and abundance } \\
\text { of antimony. }\end{array}$ \\
\hline $0 F-83-307$ & $\begin{array}{l}\text { Leach, Hopkins, Domenico, and } \\
\text { Dawson (1984d). }\end{array}$ & $\begin{array}{l}\text { Geochemical distribution and abundance } \\
\text { of copper. }\end{array}$ \\
\hline $0 F-83-308$ & $\begin{array}{l}\text { Leach, Hopkins, Domenico, and } \\
\text { Goldfarb (1984a). }\end{array}$ & $\begin{array}{l}\text { Geochemical distribution and abundance } \\
\text { of zinc. }\end{array}$ \\
\hline OF-83-309 & $\begin{array}{l}\text { Leach, Hopkins, Domenico, and } \\
\text { Goldfarb (1984b). }\end{array}$ & $\begin{array}{l}\text { Geochemical distribution and abundance } \\
\text { of silver. }\end{array}$ \\
\hline $0 F-84-700$ & Leach and Domenico (1985) - & $\begin{array}{l}\text { Geochemical distribution and abundance } \\
\text { of bismuth, molybdenum, tin, and } \\
\text { tungsten. }\end{array}$ \\
\hline
\end{tabular}

${ }^{1}$ Open-file reports for the Wallace quadrangle include basic geochemical and geophysical data, 35- mm slides of preliminary maps that are or will be superseded by maps of the I or MF series (see table 1), and black and white maps of selected data that are shown only in combined forms on other maps of the folio. 
BIBLIOGRAPHY OF THE WALLACE $1^{\circ} \times 2^{\circ}$ QUADRANGLE

(including unpublished data sources)

*indicates reports of the CUSMAP project

Aadland, R. K., 1977, Cambrian carbonates in the Libby trough, northwest Montana: Geological Society of America Abstracts with Programs, v. 9, no. 6, p. 705.

Alden, W. C., 1953, Physiography and glacial geology of western Montana and adjacent areas: U.S. Geological Survey Professional Paper 231, 200 p.

Anderson, A. L., 1928, A geological reconnaissance in the St. Maries region, Idaho: Idaho Bureau of Mines and Geology Pamphlet 30, $22 \mathrm{p}$.

Armstrong, R. L., 1975, The geochronometry of Idaho: Isochron/West, no. 14, p. 1-50.

1976, The geochronometry of Idaho: Isochron/West, no. 15 , p. $1-33$.

Armstrong, R. L., Taubeneck, W. H., and Hales, P. O., 1977, $\mathrm{Rb}-\mathrm{Sr}$ and $\mathrm{K}-\mathrm{Ar}$ geochronometry of Mesozoic granitic rocks and their $\mathrm{Sr}$ isotopic composition, Oregon, Washington, and Idaho: Geological Society of America Bulletin, v. 88, no. 3, p. 397-411.

*Bankey, Viki, Brickey, Mike, and Kleinkopf, M. D., 1982, Principal facts for 1980 gravity stations in the Wallace $1^{\circ} \times 2^{\circ}$ quadrangle, Montana-Idaho: U.S. Geological Survey Open-File Report 82-132.

*Bankey, Viki, and Kleinkopf, M. D., 1982, Principal facts for the Bouguer gravity map of the Wallace $1^{\circ} \times 2^{\circ}$ CUSMAP quadrangle: U.S. Geological Survey Open-File Report 82 883.

Bell, Robert, 1908, Ninth annual report on the mining industry of Idaho for the year 1907: State Mine Inspector's Report, $217 \mathrm{p}$.

Billingsley, P. R., and Locke, Augustus, 1939, Structure of ore districts in the continental framework: New York, American Institute of Mining and Metallurgical Engineers, $51 \mathrm{p}$.

Bondurant, K. T., and Lawson, D. C., 1969, Directory of mining enterprises for 1968: Montana Bureau of Mines and Geology Bulletin 72, 65 p.

Bowden, T. D., 1977, Depositional processes and environments within the Revett Formation, Precambrian Belt Supergroup, northwestern Montana and northern Idaho: Riverside, Calif., University of California at Riverside M.S. thesis, $161 \mathrm{p}$.

Calkins, F. C., and Jones, E. L., Jr., 1914, Economic geology of the region around Mullan, Idaho, and Saltese, Montana: U.S. Geological Survey Bulletin 540-E, p. 167-211.

Campbell, A. B., 1960 [1961], Geology and mineral deposits of the St. Regis-Superior area, Mineral County, Montana: U.S. Geological Survey Bulletin 1082-I, p. 545-612.

Campbell, Stewart, 1922, Twenty-third annual report on the mining industry of Idaho for the year 1921: State Mine Inspector's Report, $152 \mathrm{p}$.

1923, Twenty-fourth annual report on the mining industry of Idaho for the year 1922: State Mine Inspector's Report, 209 p.
1924, Twenty-fifth annual report on the mining industry of Idaho for the year 1923: State Mine Inspector's Report, $121 \mathrm{p}$.

1924, Twenty-sixth annual report on the mining industry of Idaho for the year 1924: State Mine Inspector's Report, 249 p.

1927, Twenty-eighth annual report on the mining industry of Idaho for the year 1926: State Mine Inspector's Report, $269 \mathrm{p}$.

Cannon, R. S., Jr., Pierce, A. P., Antweiler, J. C., and Buck, K. L., 1962, Lead-isotope studies in the northern Rockies, U.S.A., in Petrologic studies-A volume in honor of A. F. Buddington: Geological Society of America, p. 115-131.

Carter, R. A., and Li, T. M., 1976, Idaho's Coeur d'Alene district sets sights on record production: Mining Engineering, v. 28 , no. 7 , p. $49-64$.

*Chesson, Sharon, Wallace, R. R., and Griffith, Thomas, 1984, Maps showing mineral occurrence data for the Wallace $1^{\circ} \times 2^{\circ}$ quadrangle, Montana and Idaho: U.S. Geological Survey Miscellaneous Field Studies Map MF-1354-F.

Chevillon, C. V., 1977, Tectonically induced, Proterozoic soft sediment deformation at the Atlas property, Coeur d'Alene mining district, Idaho: Geological Society of America Abstracts with Programs, v. 9, no. 6, p. 716.

Collier, A. J., 1906, Ore deposits in the St. Joe River basin, Idaho: U.S. Geological Survey Bulletin 285-B, p. 129-139.

Cook, E. F., 1955, Prospecting for uranium, thorium, and tungsten in Idaho: Idaho Bureau of Mines and Geology Pamphlet 102, $53 \mathrm{p}$.

*Cressman, E. R., 1981, Geologic map of parts of the Plains and Perma quadrangles, western Montana: U.S. Geological Survey Open-File Report 81-785.

* _ 1982, Generalized stratigraphic section of the Prichard Formation, basal Belt Supergroup, Proterozoic Y, near Plains, Montana: U.S. Geological Survey Open-File Report 82-495.

1985, The Prichard Formation of the lower part of the Belt Supergroup (middle Proterozoic) near Plains, Sanders County, Montana: U.S. Geological Survey Bulletin 1553, 64 p.

Crosby, G. M., 1969, A preliminary examination of trace mercury in rocks, Coeur d'Alene district, Idaho: Quarterly of the Colorado School of Mines, v. 64, no. 1, p. 169-194.

Crowley, F. A., 1960, Directory of known mining enterprises, 1959: Montana Bureau of Mines and Geology Bulletin 14, $64 \mathrm{p}$.

1962, Directory of known mining enterprises, 1961: Montana Bureau of Mines and Geology Bulletin 25, $71 \mathrm{p}$.

1963, Mines and mineral deposits (except fuels), Sanders County, Montana: Montana Bureau of Mines and Geology Bulletin 34, 58 p.

Daniel, Faith, and Berg, R. B., 1981, Radiometric dates of rocks in Montana: Montana Bureau of Mines and Geology Bulletin 114, $118 \mathrm{p}$.

Day, D. T., and Richards, R. H., 1906, Black sands of the Pacific slope: U.S. Geological Survey Mineral Resources of the United States, 1905, p. 1175-1246.

DeMunck, V. C. E. A., and Ackerman, W. C., 1958, Barite deposits in Montana: Montana Bureau of Mines and Geology Information Circular 22, $30 \mathrm{p}$. 
Douglas, J. K., 1972, Geophysical investigation of the Montana lineament: Missoula, Mont., University of Montana, M.S. thesis, $75 \mathrm{p}$.

Earhart, R. L., and Van Loenen, R. E., 1981, Unpublished U.S. Geological Survey data on the platinum-palladium occurrences near Dixon, Mont.

Earhart, R. L., Van Loenen, R. E., and Whipple, J. W., 1980, Unpublished U.S. Geological Survey data on mineral resources of the Flathead Indian Reservation, Montana.

Engineering and Mining Journal, 1976, Asarco's newly dedicated Coeur Silver Mine will be fourth largest in U.S.: Engineering and Mining Journal, v. 177, no. 7, p. 23-27.

Fletcher, G. D., 1959, Sixtieth annual report on the mining industry of Idaho for the year 1959: State Mine Inspector's Report, 116 p.

1960 , Sixty-first annual report on the mining industry of Idaho for the year 1960: State Mine Inspector's Report, $113 \mathrm{p}$.

1962, Sixty-third annual report on the mining industry of Idaho for the year 1962: State Mine Inspector's Report, $113 \mathrm{p}$.

Folwell, W. T., 1958, Lucky Friday mine [Idaho]-History, geology, and development: Mining Engineering, v. 10, no. 12 , p. $1266-1268$.

Fryklund, V. C., Jr., 1964, Ore deposits of the Coeur d'Alene district, Shoshone County, Idaho, with a section on The bleached rock in the Coeur d'Alene district by P. L. Weis: U.S. Geological Survey Professional Paper 445, 103 p.

Geach, R. D., 1965, Directory of mining enterprises for 1964: Montana Bureau of Mines and Geology Bulletin 46, $81 \mathrm{p}$.

1968, Directory of mining enterprises for 1967: Montana Bureau of Mines and Geology Bulletin 67, $93 \mathrm{p}$.

Geach, R. D., and Chelini, J. M., 1963, Directory of known mining enterprises, 1962: Montana Bureau of Mines and Geology Bulletin 33, 84 p.

Gerry, C. N., 1922, Gold, silver, copper, lead, and zinc in Idaho: U.S. Geological Survey Mineral Resources of the United States, 1920, Part 1, Metals, p. 239-259.

1925, Gold, silver, copper, lead, and zinc in Idaho: U.S. Geological Survey Mineral Resources of the United States, 1922, Part 1, Metals, p. 217-244.

Gibson, Russell, 1948, Geology and ore deposits of the Libby quadrangle, Montana, with sections on Pleistocene glaciation by W. C. Alden, and Physiography by J. T. Pardee: U.S. Geological Survey Bulletin 956, 131 p.

Gibson, Russell, Jenks, W. F., and Campbell, Ian, 1941, Stratigraphy of the Belt Series in the Libby and Trout Creek quadrangles, northwestern Montana and northern Idaho: Geological Society of America Bulletin 52, no. 3, p. $363-380$.

Gilbert, F. C., 1935, Directory of Montana mining properties: Montana Bureau of Mines and Geology Memoir 15, 99 p.

Gott, G. B., and Cathrall, J. B., 1980, Geochemical-exploration studies in the Coeur d'Alene district, Idaho and Montana: U.S. Geological Survey Professional Paper 1116, 63 p.

Harrison, J. E., 1972, Precambrian Belt basin of northwestern United States: Its geometry, sedimentation, and copper occurrences: Geological Society of America Bulletin, v. 83, no. 5, p. 1215-1240.
1974, Copper mineralization in miogeosynclinal clastics of the Belt Supergroup, northwestern United States, in Gisements stratiformes et provinces cupriferes: Geological Society of Belgium Special Paper, p. 353-366.

*Harrison, J. E., Cressman, E. R., Long, C. L.. Leach, D. L., and Domenico, J. A., in press, Resource appraisal map for Sullivan-type stratabound lead-zinc-silver deposits in the Wallace $1^{\circ} \times 2^{\circ}$ quadrangle, Montana and Idaho: U.S. Geological Survey Miscellaneous Investigations Series I-1509-G.

*Harrison, J. E., Domenico, J. A., and Leach, D. L., in press, Resource appraisal map for placer gold in the Wallace $1^{\circ} \times 2^{\circ}$ quadrangle, Montana and Idaho: U.S. Geological Survey Miscellaneous Investigations Series I-1509-E.

in press, Resource appraisal map for stratabound copper-silver deposits in the Wallace $1^{\circ} \times 2^{\circ}$ quadrangle, Montana and Idaho: U.S. Geological Survey Miscellaneous Investigations Series I-1509-F.

Harrison, J. E., Griggs, A. B., and Wells, J. D., 1974, Tectonic features of the Precambrian Belt basin and their influence on post-Belt structures: U.S. Geological Survey Professional Paper 866, 15 p.

* 1981, Generalized geologic map of the Wallace $1^{\circ} \times 2^{\circ}$ quadrangle, Montana and Idaho: U.S. Geological Survey Miscellaneous Field Studies Map MF-1354-A.

* ___ in press, Geologic and structure maps of the Wallace $1^{\circ} \times 2^{\circ}$ quadrangle, Montana and Idaho: U.S. Geological Survey Miscellaneous Investigations Series I-1509-A.

Harrison, J. E., and Jobin, D. A., 1963, Geology of the Clark Fork quadrangle, Idaho-Montana: U.S. Geological Survey Bulletin 1141-K, 38 p.

Harrison, J. E., Kleinkopf, M. D., and Wells, J. D., 1980, Phanerozoic thrusting in Proterozoic Belt rocks, northwestern United States: Geology, v. 8, no. 9, p. 407-411.

*Harrison, J. E., Leach, D. L., and Kleinkopf, M. D., in press, Resource appraisal maps for mesothermal base- and precious-metal veins in the Wallace $1^{\circ} \times 2^{\circ}$ quadrangle, Montana and Idaho: U.S. Geological Survey Miscellaneous Investigations Series I-1509-I.

*Harrison, J. E., Leach, D. L., Kleinkopf, M. D., Cressman, E. R., Long, C. L., and Domenico, J. A., 1982, Preliminary resource appraisal for metallic minerals in the Wallace $1^{\circ} \times 2^{\circ}$ quadrangle, Montana and Idaho: U.S. Geological Survey Open-File Report 82-581 (nine 35-mm colored slides).

* ___ in press, Summary map of resource potential for metallic minerals in the Wallace $1^{\circ} \times 2^{\circ}$ quadrangle, Montana and Idaho: U.S. Geological Survey Miscellaneous Investigations Series I-1509-J.

*Harrison, J. E., Leach, D. L., Kleinkopf, M. D., and Long, C. L., in press, Resource appraisal map for porphyry molybdenum-tungsten, platinum-group metals, and epithermal silver deposits in the Wallace $1^{\circ} \times 2^{\circ}$ quadrangle, Montana and Idaho: U.S. Geological Survey Miscellaneous Investigations Series I-1509-H.

Hietanen, Anna, 1963, Anorthosite and associated rocks in the Boehls Butte quadrangle and vicinity, Idaho: U.S. Geological Survey Professional Paper 344-B, pl. 1, scale 1:48,000. 
1968, Belt Series in the region around Snow Peak and Mallard Peak, Idaho: U.S. Geological Survey Professional Paper 344-E, pls. 1 and 2, scale 1:48,000.

1969, Distribution of $\mathrm{Fe}$ and $\mathrm{Mg}$ between garnet, staurolite, and biotite in aluminum-rich schist in various metamorphic zones north of the Idaho batholith: American Journal of Science, v. 267, p. 422-456.

Hobbs, S. W., Griggs, A. B., Wallace, R. E., and Campbell, A. B., 1965, Geology of the Coeur d'Alene district, Shoshone County, Idaho: U.S. Geological Survey Professional Paper 478, 139 p.

*Hopkins, D. M., in press, Multielement analyses techniques for partial and total metal extraction of stream sediments-Application to stream sediment sampling in the Wallace $1^{\circ} \times 2^{\circ}$ quadrangle, Montana and Idaho: Journal of Geochemical Exploration.

Hosterman, J. W., 1956, Geology of the Murray area, Shoshone County, Idaho: U.S. Geological Survey Bulletin 1027-P, p. 725-748.

Hunt, Graham, 1962, Time of Purcell eruption in southeastern British Columbia and southwestern Alberta: Journal of Alberta Society of Petroleum Geologists, v. 10, no. 7, p. 438442.

Johns, W. M., 1962, Progress report on geologic investigations in the Kootenai-Flathead area, northwest Montana-Report 4, Southwestern Flathead County: Montana Bureau of Mines and Geology Bulletin 29, 38 p.

1964, Progress report on geologic investigations in the Kootenai-Flathead area, northwest Montana-Report 6, Southeastern Flathead County and northern Lake County: Montana Bureau of Mines and Geology Bulletin 42, $66 \mathrm{p}$.

1970, Geology and mineral deposits of Lincoln and Flathead Counties, Montana: Montana Bureau of Mines and Geology Bulletin 79, $182 \mathrm{p}$.

Johns, W. M., Smith, A. G., Barnes, W. C., Gilmour, E. H., and Page, W. D., 1963, Progress report on geologic investigations in the Kootenai-Flathead area, northwest Montana-Report 5, Western Flathead County and part of Lincoln County: Montana Bureau of Mines and Geology Bulletin 36, 68 p.

Jones, E. L., Jr., 1920, A reconnaissance of the Pine Creek district, Idaho: U.S. Geological Survey Bulletin 710-A, p. $1-36$.

Keim, J. W., and Rector, R. J., 1964, Paleozoic rocks in northwestern Montana-A newly recognized occurrence: Geological Society of America Bulletin, v. 75, no. 6, p. 575-578.

*Kleinkopf, M. D., and Harrison, J. E., 1982, The application of aeromagnetic and gravity anomaly maps on mineral resource assessments of the Wallace quadrangle, northern Rocky Mountains: Society of Exploration Geophysicists, 52nd Annual Meeting, Dallas, Texas, Technical Program, Abstracts and Biographies, p. 310-311.

*Kleinkopf, M. D., Harrison, J. E., and Bankey, Viki, 1982, Slides showing aeromagnetic and gravity anomaly maps and a metallic mineral resource favorability map of the Wallace $1^{\circ} \times 2^{\circ}$ quadrangle, Montana and Idaho: U.S. Geological Survey Open-File Report 82-709 (three 35-mm colored slides). in press, Aeromagnetic and gravity anomaly maps and a hydrothermal veins favorability map of the Wallace $1^{\circ} \times 2^{\circ}$ quadrangle, Montana and Idaho: U.S. Geological Survey Miscellaneous Field Studies Map MF-1354-E.

Kleinkopf, M. D., Harrison, J. E., and Zartman, R. E., 1972 , Aeromagnetic and geologic map of part of northwestern Montana and northern Idaho: U.S. Geological Survey Geophysical Investigations Map GP-830.

*Kleinkopf, M. D., and Long, C. L., 1979, Geophysical studies in the Wallace quadrangle, northern Belt basin, Montana and Idaho: Northwest Mining Association, 85th Annual Convention, Spokane, Washington, Program, p. 15.

Lang, H. M., and Rice, J. M., 1982, Geothermometry and geobarometry of metapelites, Snow Peak, N. Idaho: Geological Society of America Abstracts with Programs, v. 14 , no. 6 , p. 318 .

LaPoint, D. J., 1971, Geology and geophysics of the southwestern Flathead Lake region, Montana: Missoula, Mont., University of Montana M.S. thesis, $110 \mathrm{p}$.

Larsen, E. S., Jr., Gottfried, David, Jaffe, H. W., and Waring, C. L., 1958, Lead-alpha ages of the Mesozoic batholiths of western North America: U.S. Geological Survey Bulletin 1070-B, p. 35-62.

Lawson, D. C., 1972, Directory of mining enterprises for 1971: Montana Bureau of Mines and Geology Bulletin 86, $42 \mathrm{p}$. 1973, Directory of mining enterprises for 1972: Montana Bureau of Mines and Geology Bulletin 88, 57 p. 1975, Directory of mining enterprises for 1974: Montana Bureau of Mines and Geology Bulletin 95, 64 p.

1977, Directory of mining enterprises for 1976: Montana Bureau of Mines and Geology Bulletin 103, $58 \mathrm{p}$.

1978, Directory of mining enterprises for 1977: Montana Bureau of Mines and Geology Bulletin 107, $56 \mathrm{p}$.

*Leach, D. L., 1982, Geochemical favorability for mesothermal veins in the Wallace $1^{\circ} \times 2^{\circ}$ quadrangle, Montana and Idaho: U.S. Geological Survey Open-File Report 82-577 (one 35-mm colored slide).

* ___ in press, Geochemical favorability for mesothermal base- and precious-metal veins in the Wallace $1^{\circ} \times 2^{\circ}$ quadrangle, Montana and Idaho: U.S. Geological Survey Miscellaneous Field Studies Map MF-1354-C.

*Leach, D. L., and Domenico, J. A., 1985, Distribution of samples of nonmagnetic heavy-mineral concentrates having anomalous concentrations of bismuth, molybdenum, tin, and tungsten from the Wallace $1^{\circ} \times 2^{\circ}$ quadrangle, Montana and Idaho: U.S. Geological Survey Open-File Report 84 $700,7 \mathrm{p}$.

in press, Geochemical map showing distribution of samples of nonmagnetic heavy-mineral concentrates that contain anomalous concentrations of antimony, arsenic, copper, lead, silver, and zinc in the Wallace $1^{\circ} \times 2^{\circ}$ quadrangle, Montana and Idaho: U.S. Geological Survey Miscellaneous Investigations Series I-1509-B.

*Leach, D. L., Domenico, J. A., Hopkins, D. M., Dawson, H. E., and Goldfarb, R. J., 1982, Data report and statistical summary for samples of stream-sediment and nonmagnetic heavy-mineral concentrates from the Wallace $1^{\circ} \times 2^{\circ}$ quadrangle, Montana and Idaho: U.S. Geological Survey Open-File Report 82-494. 
*Leach, D. L., and Goldfarb, R. J., 1982, Geochemical favorability for mesothermal base- and precious-metal veins in the Wallace $1^{\circ} \times 2^{\circ}$ quadrangle, Montana and Idaho: Geological Society of America Abstracts with Programs, v. 14, no. 7, p. 543 .

*____ in press, Maps showing the distribution of the sum of the ranks for concentrations of lead, zinc, copper, and silver, and of lead and zinc in samples of stream sediment from the Wallace $1^{\circ} \times 2^{\circ}$ quadrangle, Montana and Idaho: U.S. Geological Survey Miscellaneous Field Studies Map MF-1354-D.

*Leach, D. L, and Hopkins, D. M., in press, Geochemical map showing distribution of stream-sediment samples that contain anomalous concentrations of antimony, bismuth, cadmium, copper, lead, silver, and zine from the Wallace $1^{\circ} \times 2^{\circ}$ quadrangle, Montana and Idaho: U.S. Geological Survey Miscellaneous Investigations Series I-1509-C.

*____ in press, Geochemical map showing distribution of stream-sediment samples that contain anomalous concentrations of partially-extractable antimony, bismuth, copper, lead, silver, and zinc from the Wallace $1^{\circ} \times 2^{\circ}$ quadrangle, Montana and Idaho: U.S. Geological Survey Miscellaneous Investigations Series I-1509-D.

*Leach, D. L., Hopkins, D. M., Domenico, J. A., and Dawson, H. E., 1984a, Distributions of total lead in samples of nonmagnetic heavy-mineral concentrate and of total and partially-extractable lead in samples of stream sediment from the Wallace $1^{\circ} \times 2^{\circ}$ quadrangle, Montana and Idaho: U.S. Geological Survey Open-File Report 83-304.

* _ 1984b, Distributions of total cadmium in samples of nonmagnetic heavy-mineral concentrate and of total and partially-extractable cadmium in samples of stream sediment from the Wallace $1^{\circ} \times 2^{\circ}$ quadrangle, Montana and Idaho: U.S. Geological Survey Open-File Report $83-305$.

*___ 1984c, Distributions of total antimony in samples of nonmagnetic heavy-mineral concentrate and of total and partially-extractable antimony in samples of stream sediment from the Wallace $1^{\circ} \times 2^{\circ}$ quadrangle, Montana and Idaho: U.S. Geological Survey Open-File Report 83-306.

* _ 1984d, Distributions of total copper in samples of nonmagnetic heavy-mineral concentrate and of total and partially-extractable copper in samples of stream sediment from the Wallace $1^{\circ} \times 2^{\circ}$ quadrangle, Montana and Idaho: U.S. Geological Survey Open-File Report 83-307.

*Leach, D. L., Hopkins, D. M., Domenico, J. A., and Goldfarb, R. J., 1984a, Distributions of total zinc in samples of nonmagnetic heavy-mineral concentrate and of total and partially-extractable zinc in samples of stream sediment from the Wallace $1^{\circ} \times 2^{\circ}$ quadrangle, Montana and Idaho: U.S. Geological Survey Open-File Report 83-308.

* _ 1984b, Distributions of total silver in samples of nonmagnetic heavy-mineral concentrate and of total and partially-extractable silver in samples of stream sediment from the Wallace $1^{\circ} \times 2^{\circ}$ quadrangle, Montana and Idaho: U.S. Geological Survey Open-File Report 83-309.

Long, Austin, Silverman, A. J., and Kulp, J. L., 1960, Isotopic composition of lead and Precambrian mineralization of the Coeur d'Alene district, Idaho: Economic Geology, v. 55, no. 4 , p. $645-658$.
*Long, C. L., 1982, Preliminary audio-magnetotelluric results for part of the Wallace $1^{\circ} \times 2^{\circ}$ quadrangle, Montana and Idaho: U.S. Geological Survey Open-File Report 82-671 (four 35-mm colored slides).

1983, Maps showing results of audio-magnetotelluric studies in the northwestern part of the Wallace $1^{\circ} \times 2^{\circ}$ quadrangle, Montana and Idaho: U.S. Geological Survey Miscellaneous Field Studies Map MF-1354-B.

*Long, Carl, Tippens, Charles, and Lewis, Vernon, 1981, Audio-magnetotelluric data $\log$ and station-location map for part of the Wallace $1^{\circ} \times 2^{\circ}$ quadrangle, Idaho and Montana: U.S. Geological Survey Open-File Report 81-1153.

Lyden, C. J., 1948, The gold placers of Montana: Montana Bureau of Mines and Geology Memoir 26, $151 \mathrm{p}$.

MacDonald, D. F., 1906, Economic features of northern Idaho and northwestern Montana: U.S. Geological Survey Bulletin 285-A, p. 41-52.

Marvin, R. F., and Dodson, S. W., 1979, Radiometric agesCompilation B, U.S. Geological Survey: Isochron/West, no. 26 , p. $3-32$.

*Marvin, R. F., Zartman, R. E., Obradovich, J. D., and Harrison, J. E., 1984, Geochronometric and lead isotope data on samples from the Wallace $1^{\circ} \times 2^{\circ}$ quadrangle, Montana and Idaho: U.S. Geological Survey Miscellaneous Field Studies Map MF-1354-G.

*McDanal, S. K., Hopkins, D. M., and Domenico, J. A., 1982 , Spectrographic and chemical analysis of stream sediments and concentrate samples from the Wallace $1^{\circ} \times 2^{\circ}$ quadrangle, Montana and Idaho: U.S. Geological Survey Report GS-82-013 (available only from U.S. Department of Commerce, National Technical Information Service, Springfield, Va., 22151).

McDowell, C. A., 1951, Fifty-third annual report on the mining industry of Idaho for the year 1951: State Mine Inspector's Report, 174 p.

1952, Fifty-fourth annual report on the mining industry of Idaho for the year 1952: State Mine Inspector's Report, $188 \mathrm{p}$.

1955, Fifty-seventh annual report on the mining industry of Idaho for the year 1955: State Mine Inspector's Report, $157 \mathrm{p}$.

1957, Fifty-eighth annual report on the mining industry of Idaho for the year 1957: State Mine Inspector's Report, $176 \mathrm{p}$.

McDowell, F. W., 1971, K-Ar ages of igneous rocks from the western United States: Isochron/West, no. 2, p. 1-16.

Miller, R. N., 1959, Geology of the South Moccasin Mountains, Fergus County, Montana: Montana Bureau of Mines and Geology Memoir 37, 44 p.

Montana Bureau of Mines and Geology, 1973, Directory of mining enterprises, 1972: Montana Bureau of Mines and Geology Bulletin 88, $59 \mathrm{p}$.

1976, Directory of mining enterprises, 1975: Montana Bureau of Mines and Geology Bulletin 100, 63 p.

Moore, H. A., 1910, East Coeur d'Alene mining district, Montana: Mining World, v. 33, p. 271-276.

Mudge, M. R., Harrison, J. E., and Kleinkopf, M. D., 1976, Status of mineral resource information for the Flathead Indian Reservation: Bureau of Indian Affairs Administrative Report, BIA-22. 
Noranda Exploration Staff, Missoula, Montana, 1980, Unpublished data on the Liver Peak molybdenite prospect, Montana.

Obradovich, J. D., and Peterman, Z. E., 1968, Geochronology of the Belt Series, Montana: Canadian Journal of Earth Sciences, v. 5 , no. 3, p. 737-747.

Page, W. D., 1963, Reconnaissance geology of the north quarter of the Horse Plains quadrangle, Montana: Boulder, Colo., University of Colorado M.S. thesis, 40 p.

Pardee, J. T., 1910, The glacial Lake Missoula: Journal of Geology, v. 18 , p. $376-386$.

1911, Geology and mineralization of the upper St. Joe River basin, Idaho: U.S. Geological Survey Bulletin 470-B, p. 39-61.

Ransome, F. L., and Calkins, F. C., 1908, The geology and ore deposits of the Coeur d'Alene district, Idaho: U.S. Geological Survey Professional Paper 62, 203 p.

Reid, R. R., ed., 1961, Guidebook to the geology of the Coeur d'Alene mining district: Idaho Bureau of Mines and Geology Bulletin 16, $37 \mathrm{p}$.

Reid, R. R., and Greenwood, W. R., 1968, Multiple deformation and associated progressive polymetamorphism in the Beltian rocks north of the Idaho batholith, Idaho, U.S.A.: International Geological Congress, 23rd, Prague, 1968, Proceedings, v. 4, p. 75-87.

Reid, R. R., Morrison, D. A., and Greenwood, W. R., 1973, The Clearwater orogenic zone: $A$ relict of Proterozoic orogeny in central and northern Idaho: Belt Symposium, Department of Geology, University of Idaho, Moscow, Idaho, p. 10-56.

Reyner, M. L., and Trauerman, C. J., 1949, Directory of Montana mining properties: Montana Bureau of Mines and Geology Memoir 31, 125 p.

*Rowan, L. C., and Purdy, T. L., in press, Interpretation of lineament data for the Wallace $1^{\circ} \times 2^{\circ}$ quadrangle, Montana and Idaho: U.S. Geological Survey Miscellaneous Field Studies Map MF-1354-H.

Rowe, J. P., 1911, Geology and ores of the Carter district, Montana: Mining and Engineering World, v. 35, p. 579-581.

1911, Gold quartz mining in western Montana: Mining and Engineering World, v. 34, p. 1033-1034.

Sahinen, U. M., 1957, Mines and mineral deposits Missoula and Ravalli Counties, Montana: Montana Bureau of Mines and Geology Bulletin 8, $63 \mathrm{p}$.

Schrader, F. C., 1911, Gold-bearing ground moraine in northwestern Montana: U.S. Geological Survey Bulletin 470-B, p. $62-74$.

Shenon, P. J., 1938, Geology and ore deposits near Murray, Idaho: Idaho Bureau of Mines and Geology Pamphlet 47, $44 \mathrm{p}$.

Shenon, P. J., and Taylor, A. V., Jr., 1936, Geology and ore occurrence of the Hog Heaven mining district, Flathead County, Montana: Montana Bureau of Mines and Geology Memoir 17, 26 p.
Stout, K. S., and Ackerman, W. C., 1958, Directory of known mining enterprises of Montana, 1957: Montana Bureau of Mines and Geology Information Circular 20, $57 \mathrm{p}$.

1959, Directory of known mining enterprises, 1958: Montana Bureau of Mines and Geology Bulletin 10, $80 \mathrm{p}$.

Trauerman, C. J., and Waldron, C. R., 1940, Directory of Montana mining properties: Montana Bureau of Mines and Geology Memoir 20, 135 p.

Umpleby, J. B., and Jones, E. L., Jr., 1923, Geology and ore deposits of Shoshone County, Idaho: U.S. Geological Survey Bulletin 732, $156 \mathrm{p}$.

U.S. Bureau of Mines, 1981, Minerals Availability System.

U.S. Department of Energy, 1981, Aerial radiometric and magnetic survey, Wallace national topographic map, Idaho/Montana: Bendix Field Engineering Subcontract No. 80-447-S by Geodata International, Inc., Dallas, Texas. DOE Open-File Report GJBX-111(81).

U.S. Forest Service Mineral Occurrence Files, 1980, Missoula, Montana.

U.S. Geological Survey, 1973, Aeromagnetic map of parts of the Spokane and Wdllace $1^{\circ} \times 2^{\circ}$ quadrangle, Idaho: U.S. Geological Survey Open-File Report.

1979, Aeromagnetic map of the Wallace-Flathead area, Montana: U.S. Geological Survey Open-File Report 79 713 , scale 1:62,500.

1981, Computerized Resource Information Bank (Mineral Resource Data System).

Wagner, W. R., 1949, The geology of part of the south slope of the St. Joe Mountains, Shoshone County, Idaho: Idaho Bureau of Mines and Geology Pamphlet 82, $48 \mathrm{p}$.

Wallace, R. E., and Hosterman, J. W., 1956, Reconnaissance geology of western Mineral County, Montana: U.S. Geological Survey Bulletin 1027-M, p. 575-612.

Weis, P. L., Armstrong, F. C., and Rosenblum, Samuel, 1958 [1959], Reconnaissance for radioactive minerals in Washington, Idaho, and western Montana: U.S. Geological Survey Bulletin 1074-B, p. 7-48.

Wells, J. D., 1974 [1975], Geologic map of the Alberton quadrangle, Missoula, Sanders, and Mineral Counties, Montana: U.S. Geological Survey Geologic Quadrangle Map GQ-1157, scale 1:62,500.

Wilson, D. M., 1979, Principal facts for gravity stations in the Wallace $1^{\circ} \times 2^{\circ}$ quadrangle, Montana and Idaho: U.S. Geological Survey Open-File Report 79-1309.

Wilson, R. S., 1963, Geochemical exploration reconnaissance of the Avery area, Idaho: Moscow, Idaho, University of Idaho M.S. thesis, 81 p.

Wold, R. J., 1982, Seismic reflection study of Flathead Lake, Montana: U.S. Geological Survey Miscellaneous Field Studies Map MF-1433.

Zartman, R. E., and Stacey, J. S., 1971, Lead isotopes and mineralization ages in Belt Supergroup rocks, northwestern Montana and northern Idaho: Economic Geology, v. 66 , no. 6 , p. $849-860$. 

. 
